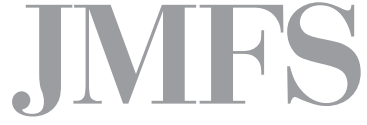

Journal of Management and Financial Sciences
Volume XII

Issue 38 (September 2019)

pp. 61-83

Warsaw School of Economics

Collegium of Management and Finance

Qiang Qiu, Tongxun Zhang

International Development Cooperation Institute

International Business School

Shanghai University of International Business and Economics

\title{
Impact of host countries' environmental regulations along the Belt and Road Initiative on China's Outward Foreign Direct Investment ${ }^{1}$
}

\begin{abstract}
This paper makes use of the panel data of China's direct investment in 61 countries along the 'Belt and Road' from 2006 to 2016. Using the investment gravity model, we first carry out the total data regression, then the sample data regression based on the national income, the environmental regulation intensity and the district position. The study found that, as far as the overall sample is concerned, the national environmental regulation along the 'Belt and Road' has a significant inhibitory effect on China's Outward Foreign Direct Investment (OFDI), and the countries along the line are grouped according to income levels. Environmental regulations vary according to the differences in national income levels: environmental regulations in high income and intermediate-high income countries have a notable negative correlation with the OFDI of China, while environmental regulations in low-and middle-income countries have no significant impact on China's OFDI. According to the intensity of environmental regulation, the countries along the 'Belt and Road' are grouped. The empirical results show that China’s OFDI was significantly inhibited by countries whose national environmental regulations are higher than the Environmental Performance Index (EPI), while China's OFDI was not affected by the countries whose national environmental regulations are lower than the EPI. According to the different regional groupings of the host country, it was found that the
\end{abstract}

1 The completion of this achievement was supported by the 2016 National Social Science Fund Major Project China International Assistance and Development Cooperation System Innovation Research (Project Approval No. 16ZDA037). 
environmental regulations of European countries and West Asian countries significantly inhibited China's OFDI, while the environmental regulations of the Middle East and North Africa and East Asian countries had no significant impact on China's OFDI.

Some other important factors affecting China's OFDI should be taken into consideration, including the scale of the economy in the investment home country, the host country's economic level, strategic resources, infrastructure, government regulation, and bilateral trade tightness. Except for the government regulation level, which has an inhibitory effect on China's OFDI, the others have a strong promoting effect. This is consistent with the conclusions drawn by Qiu Qiang [2018]. The role of natural resources is not significant, indicating that China has insufficient incentives to natural resources along the 'Belt and Road' countries.

Finally, from the perspective of the government and enterprises, policy recommendations are proposed relevant to China's OFDI along the 'Belt and Road'. The government should actively collect the measurement data of the host country's environmental regulations, carry out investment grading according to the strength of the environmental regulations and formulate different investment strategies accordingly. Chinese companies must pay attention to technology and innovation capabilities, which is conducive to reducing the extrusion of OFDI with similar technology levels.

Keywords: environmental regulations, OFDI, One Belt One Line, EPI Index JEL Classification Codes: F21

\section{Literature review about the impact of the host country's environmental regulations on the OFDI in the home country}

Most scholars' research has found that environmental regulations of the host country have significantly inhibited foreign direct investment. Kellenberg [2009], based on empirical analysis of the 1999-2003 data of the top 20 countries in the growth rate of US multinational corporations, concluded that environmental regulations significantly inhibited the transnational flow of capital. After studying innovative measures developed by US states to reduce emissions, W. Keller and A. Levinson [2002] found that abatement costs have a modest impediment to FDI using US FDI panel data. D.L. Millimet and J. Roy [2016] apply two new strategies to identify US manufacturing FDI and found that the extent of environmental regulations has a significant negative impact on FDI in pollution-intensive industries. Similarly, S. Chung [2014] proved that the hypothesis of the 'pollution paradise' was right, using the data (2000-2007) from Korea in foreign direct investment. Haeyeon Yoon and Almas Heshmati [2017] based on an analysis of the 2009-2015 Korean manufacturing OFDI, found that the stricter the environmental regulations of the host country, the less FDI will be.

Focusing on the countries along the 'Belt and Road' and based on the panel model analysis, Su Hongyan and Li Jingmei [2017] made a conclusion that the spatial layout of FDI in these countries has connection with the distribution of polluting enterprises in China, the environmental regulations of the host country impact the spatial layout of FDI, the environmental 
regulations of the host country and pollution-intensive industry concentration on FDI location selection along the line. Ren Li and Huang Chongjie [2015], Chen Xuan and Wu Ge [2010], and Li Guoping et al. [2013] have shown that strict environmental regulations are not conducive to attracting direct foreign investment and the heterogeneity at the national and industry levels is prominent.

Researching on the impact of the relationship between the home country OFDI and the host country's environmental regulations, U. Wagner and C. Timmins [2009] used the GMM method to validate the pollution paradise effect based on panel data from OFDI in various manufacturing industries in Germany. Using the panel data of China's direct investment in 17 countries in the Asia-Pacific region along the 'Belt and Road' from 2005 to 2016 and the investment gravitation model, Qiu Qiang et al. [2018a] found that, in terms of the overall sample, environmental regulations in the Asia-Pacific countries along the 'Belt and Road' has a significant inhibitory effect on China's OFDI. They [2018b] also used the panel data of China's direct investment in 16 countries in Central and Eastern Europe along the Belt and Road Initiative from 2005 to 2016. In terms of the overall sample, they found the environmental regulations of the Central and Eastern European countries along the Belt and Road Initiative China's OFDI also has the same inhibitory effect, which means the stronger the environmental regulations are, the stronger the inhibition of OFDI will be. As the economy is developing, the loosely regulated environment will have a greater crowding-out effect on China's OFDI.

In the analysis of the relevant literature above, it is found that there is much literature about the impact of the host country's environmental regulations on OFDI in developed countries, while the literature focusing on developing countries is less available. In the past, the literature on China is basically to study the impact of China's environmental regulations on foreign direct investment, while studying the impact of the host country environmental regulation on China's OFDI is less common. As China invests in more and more countries along the 'Belt and Road', more and more obstacles are in the way of the formation of environmental regulations in the host country. At present, only two articles written by Qiu Qiang make systematic research on the 'Belt and Road' environmental regulations on direct foreign investment, including the Asia-Pacific region and the Central and Eastern Europe. Since these two regions do not cover all the areas along the 'Belt and Road' and the two regions are not geographically connected, there is a substantial difference between their economy and geography. Considering the suitability of the results of the fragmentation study along the 'Belt and Road', if it is not applicable, will the impact of environmental regulations on the OFDI in the entire country along the line show a gradual evolution of the basic law? This paper attempts to innovate in this aspect. At first, to conduct a comprehensive study based on the impact of the national environmental regulations of the entire 'Belt and Road' on China's OFDI. Next, to analyze differences among three regions, income levels and environmental regulations, which will help improve investment cooperation between China and the countries along the Belt and Road. 


\section{China's current status of direct investment in countries along the Belt and Road}

\subsection{The scale of investment in countries along the route}

China's OFDI stocks along the 'Belt and Road' countries have shown a steady upward trend. This paper selects 61 major countries, which rose from 1.34 billion US dollars at the end of 2003 to 129.37 billion US dollars at the end of 2016. Their share in China's total OFDI stock also increased from 3.92\% to 9.53\%. In general, the countries along the 'Belt and Road' have a low proportion of total foreign investment in China, which has not exceeded $10 \%$ till now. Thus, they are not the main destinations of China's direct foreign investment. But from the perspective of future development potential, the countries along the route have huge investment space, like some relatively lower developing countries, but with a high development rate.

\subsection{Location distribution of investment in the countries along the route}

The 'Belt and Road' includes 64 countries (excluding China), widely distributed and connecting Asia, Europe, Africa and other regions. The population and economic volume involved are a large proportion in the world. Considering the serious lack of data in some countries along the route, this paper selects 61 countries along the 'Belt and Road' and divides them into four regions, namely East Asia, West Asia, Middle East and North African, and European countries.

According to the statistics of China's Foreign Direct Investment Statistics Bulletin over the past years, China's OFDI stocks in different regions along the 'Belt and Road' vary a lot. Among them, East Asia and West Asia account for the large part of it, East Asian countries more than 50\%, West Asia about 30\%, Middle East and North Africa for nearly $10 \%$ and European countries at around $2 \%$, the least proportion of investment.

\subsection{Country differences in investment in the countries along the route}

From the perspective of specific foreign investment countries, Table 1 shows China's investment stocks and the proportion of the top 20 countries in 61 countries along the 'Belt and Road' in 2016. They are Singapore, Russia, Indonesia, Laos, Kazakhstan, Vietnam, the United Arab Emirates, Pakistan, Myanmar, Thailand, Cambodia, Israel, Mongolia, Malaysia, Iran, India, Saudi Arabia, Kyrgyzstan, Tajikistan, Turkey. The investment stocks of 20 countries accounted for $92.19 \%$ of the total investment stocks of the countries along the route, and there are 17 countries with more than $\$ 2$ billion in direct investment stocks. It can be seen from the data that the gap is obvious in China's direct investment stocks in these countries. Singapore takes the first place with 33.446 billion US dollars, accounting for $25.85 \%$ of these countries 
along the 'Belt and Road'. This was followed by Russia and Indonesia, with $\$ 12.98$ billion and $\$ 9.546$ billion, respectively.

Table 1. Top 20 countries in China's investment stocks in 61 countries along the 'Belt and Road' in 2016

\begin{tabular}{|c|c|c|c|}
\hline Rank & Country & Direct Investment Stock (100 million US dollars) & Proportion (\%) \\
\hline 1 & Singapore & 334.46 & 25.85 \\
\hline 2 & Russia & 129.80 & 10.03 \\
\hline 3 & Indonesia & 95.46 & 7.38 \\
\hline 4 & Laos & 55.00 & 4.25 \\
\hline 5 & Kazakhstan & 54.32 & 4.20 \\
\hline 6 & Vietnam & 49.84 & 3.85 \\
\hline 7 & United Arab Emirates & 48.88 & 3.78 \\
\hline 8 & Pakistan & 47.59 & 3.68 \\
\hline 9 & Myanmar & 46.20 & 3.57 \\
\hline 10 & Thailand & 45.33 & 3.50 \\
\hline 11 & Cambodia & 43.69 & 3.38 \\
\hline 12 & Israel & 42.30 & 3.27 \\
\hline 13 & Mongolia & 38.39 & 2.97 \\
\hline 14 & Malaysia & 36.34 & 2.81 \\
\hline 15 & Iran & 33.31 & 2.57 \\
\hline 16 & India & 31.08 & 2.40 \\
\hline 17 & Saudi Arabia & 26.07 & 2.02 \\
\hline 18 & Kyrgyzstan & 12.38 & 0.96 \\
\hline 19 & Tajikistan & 11.67 & 0.90 \\
\hline 20 & Turkey & 10.61 & 0.82 \\
\hline \multicolumn{2}{|c|}{ Add up to } & 1192.71 & 92.19 \\
\hline
\end{tabular}

Source: own elaboration on the basis of the 2016 China Foreign Direct Investment Statistics Bulletin.

From the perspective of the income difference in host countries, China's direct investment stock vary a lot in different levels of income in countries along the 'Belt and Road'. From 2006 to 2016, China's direct investment accounted for the largest proportion in the low- and middle-income countries with $40 \%$ of its investment and its proportion was relatively stable. Secondly, the direct investment rate in high-income countries has increased significantly in recent years, from $16 \%$ in 2006 to $37.3 \%$ in 2016 . Finally, the direct investment in middleand high-income countries is in decline, top at $47.39 \%$ in 2006 , and declining slowly from 2012 to the lowest value of $25.52 \%$ in 2016 . 


\section{Theoretical assumptions and the model construction}

\subsection{Theoretical assumptions}

The factors affecting China's OFDI mainly include the environmental regulations of the host country, the kind of political system, the trade closeness between China and the host country, the distance, the natural resources of the host country, infrastructure, and strategic assets. The impact of these factors on China's OFDI, based on literature research results, includes the following aspects.

\subsubsection{Environmental regulations in the host country}

Today, with people's paying more attention to the environmental impact on economic development, when making direct investment China must take into account the influence of the host country's environmental regulations. Guo Jianwan and Tao Feng [2009] found that if the aggregate economy is not considered in the empirical analysis, the phenomenon of the 'pollution shelter' will be verified in the study of China. Li Guoping et al., [2013], as well as Ren Li and Huang Chongjie [2015] believe that strict environmental regulations will have a negative impact on attracting foreign investment, and the degree of influence has significant characteristics of industry heterogeneity and country heterogeneity. Moreover, based on a large number of documents, the stricter environmental regulations are, the more difficult it is for foreign direct investment to enter. Therefore, this paper believes that the host country's environmental regulations are negatively correlated with China's OFDI.

\subsubsection{Legal regulations in the host country}

The quality of government regulations in the host country reflects the risk and uncertainty of the host country system to a certain extent and will have an important impact on foreign investment. Joanne E Oxley [1999] believes that the quality of government regulations is an important factor affecting FDI. To successfully enter the host country, FDI must adapt to the relevant laws of the host country. B.S. Javorcik and M. Spatareanu [2005] believe that the better the legal regulatory environment of the host country is, the greater the attraction to FDI will be. If the quality of government regulation in a country or region is low, it may mean government corruption, social instability, and low government efficiency, which will increase transaction costs and reduce corporate profits [Walsh, and Yu Jiangyan, 2010]. Therefore, it is believed that the government's regulatory quality in the host country is positively related to China's OFDI.

\subsubsection{Bilateral trade closeness between China and the host country}

The bilateral trade closeness between the two countries can reflect the convenience of trade between the two countries. Generally speaking, the higher the degree of closeness is, the more trade the two countries will be, which means the closer relationship and more convenient 
trade contacts, causing more corresponding mutual foreign direct investment. Susan F. Stone and Bang Nam Jeon [2000] concluded that the two can promote each other by studying the relationship between trade and OFDI. In view of the analysis above, it is believed that the bilateral trade tightness is positively related to China's OFDI.

\subsubsection{Natural resource endowment in the host country}

Existing research still differs on the relationship between OFDI and the natural resources of the host country. One view is that China's OFDI is to obtain local resources. For example, China's rapid growth in direct investment in Africa and Latin America is to seek local natural resources. However, the countries along the 'Belt and Road' have relatively few natural resources, but China's investment is even greater. Therefore, this paper argues that China's investment motives for countries along the route are not for natural resources. Therefore, it is believed that the state of natural resources along the 'Belt and Road' countries is not relevant to China's OFDI.

\subsubsection{Distance between China and the host country}

Generally speaking, countries with relatively close distances are similar in terms of culture, language, system, history, etc., and transportation costs are lower between countries with closer distances. The same language, history and culture help to understand each others' political positions, and the close proximity helps to save transportation costs. Therefore, political and economic exchanges will be more convenient. However, the long geographical distance between the home country and the host country will mean a greater difference in politics and culture, which causes political and cultural risks and more investment costs, so that the investment among these countries declines. It is believed that the distance between China and the host country is negatively correlated with China's OFDI.

\subsubsection{The economic growth in the host country}

The economic growth rate reflects the change of a country's economic development level and market size. A country's economic growth rate decides whether its economy has greater vitality. The faster a country's economic growth is, the greater its economic development potential and market size will be, and the bigger domestic demand is. The reason why a stateowned enterprise carries out multinational operations is that it wants to expand to overseas markets. $80 \%$ of China's foreign investment companies have incentives to seek overseas markets [UNCTAD, 2006]. Therefore, it is believed that the economic growth level of the countries along the 'Belt and Road' is positively related to China's OFDI.

\subsubsection{Strategic assets in the host country}

Strategic assets (such as technology, brand, human resources, information, etc.) are one of the objectives of foreign direct investment, especially in underdeveloped countries. The purpose of foreign direct investment usually includes acquiring strategic assets of the host 
country, such as learning advanced technology and acquiring human resources. P. Deng [2003] analyzed China's M\&A cases in developed countries and found that China has the motivation to seek strategic investment from developed countries. China's strategic motivation for OFDI in the countries along the 'Belt and Road' is worth attention. It is believed that the strategic assets of the host country and China's OFDI are positively related.

\subsection{Model building}

In this paper, the institutional factors are introduced into the Anderson model. Since the country's economic scale (GDP) has a certain correlation with its environmental regulations intensity, the interaction between the host country's economic scale and its environmental regulations level (EPI) is taken as the quality of the gravity model. The other factors outside the mass and distance are set to $\mathrm{M}$, and the gravity model of international direct investment proposed by Anderson [1979] can be transformed into:

$$
T_{i j}=U_{0}\left(Y_{i}\right)^{U_{1}}\left(Y_{j}\right)^{U_{1}}\left(D_{i j}\right)^{U_{1}}\left(M_{i j}\right)^{U_{0}} X_{i j}
$$

$D_{i j}$ indicates the geographical distance of two countries or regions, and the logarithm of the two sides can be obtained.

$$
\log T_{i j}=U_{0}+U_{1} \log Y_{i}+U_{2} \log Y_{j}+U_{3} \log D_{i j}+U_{4} \log M_{i j}+\log X_{i j}
$$

This paper studies the impact of national environmental regulations along the 'Belt and Road' on China's OFDI. Therefore, adding environmental regulations to the upper model, the formula above becomes:

$$
\log T_{i j}=U_{0}+U_{1} \log Y_{i}+U_{2} \log Y_{j}+U_{3} \log D_{i j}+U_{4} \log F_{i j}+U_{5} \log E P I_{j}+\log X_{i j}
$$

Among them, $E P I_{j}$ is the environmental regulations index of the host country, $F_{i j}$ is other factors besides the environmental regulations index and geographical distance. Based on the previous studies, this paper adds the host country infrastructure factors, strategic assets factors and trade factors to the above-mentioned extended model gravity model.

Based on the data obtained and drawing on the investment gravity model of Anderson [1979], this paper analyzes the impact of national environmental regulations along the 'Belt and Road' on China's OFDI. The model is as follows:

$$
\operatorname{lnOFDI} I_{i t}=\beta_{0}+\beta_{1} E P I_{j t}+\beta_{2}\left(e p i_{-} \ln o G D P\right)_{j t}+\beta_{3} \operatorname{lncGDP_{it}}+\beta_{4} \ln d i s t_{i j-} o i l+\sum_{n} \theta_{n} C_{j t}^{n}+\lambda_{t}+\varepsilon_{i t}
$$

Among them, i stands for China, $\mathrm{j}$ stands for host country, and $\mathrm{t}$ stands for a given year. $O F D I_{i t}$ represents the stock of direct investment of China in year t to country j, $E P I_{j t}$ indicates 
the level of environmental regulation of the host country in year $t$ and country $\mathrm{j},(e p i$ ln $G D P)$ is the interaction term between the EPI and the host country's GDP, $\ln c G D P_{i t}$ represents the logarithm of China's t-year GDP, measuring the distance cost in the form of kilometres, quite different with the measurement in the past using the constant shipping distance or the distance between the national capitals. The reasons are as follows. First, the distance cost or transportation cost is various, depending on factors such as oil price. Secondly, when the fixed-effects measurement model is applied in the gravity model, the distance is treated as an individual fixed effect, which cannot be recognized. In order to overcome the shortcomings of the above practices, this paper draws on the methods of Jiang Dianchun and Zhang Qingchang [2011], using ln dist ${ }_{i j}$ oil to show the transportation cost, which is multiplied by the geographical distance between countries and the international oil price. $C_{j t}^{n}$ is the control variable, which mainly includes the economic scale, strategic assets and natural resource endowment of the host country, infrastructure, level of government regulation, and bilateral trade tightness. $\varepsilon_{i t}$ are errors.

\subsection{Variable design}

\subsubsection{Interpreted variable}

In view of the fact that China's foreign direct investment flows have a large number of negative values over the years, it will increase the uncertainty in the data analysis. Therefore, the explained variable used in this paper adopts the stock of foreign direct investment in the host countries along the 'Belt and Road'. Stocks (referred to as OFDI), the data is compiled and aggregated from the Statistical Bulletin of China's Foreign Direct Investment over the years.

\subsubsection{Explanatory variables}

The explanatory variables are the intensity of environmental regulations in the host country, because the standards of the environment regulations established by different countries are various and the method of measuring costs is difficult to unify. Therefore, it is difficult to find a unified measure of environmental regulations from the perspective of cost and input. For the reasons above, when considering the horizontal comparability and availability of data, this paper refers to the ways of Debashis Chakrabortya, Sacchidananda Mukherjeeb [2013], Zhu Shujin and Yin Shixue [2014], Gao Jing and Liu Guoguang [2014], etc., The EPI index, selected by Yale University, serves as an indicator for measuring the level of environmental regulations in the countries along the Belt and Road Initiative.

Regarding the level of environmental regulations in the countries along the 'Belt and Road', this paper ranks the average of the 2006-2016 environmental regulations index of 61 countries along the route. It can be found that the gap among different countries in environmental regulations are clearly obvious, especially the top rankings and the bottom countries. The top ten countries in environmental regulations are: Singapore, Estonia, Slovenia, Latvia, the Czech 
Republic, Greece, the Slovak Republic, Lithuania, Croatia, the Russian Federation, of which Singapore's average environmental regulations index is the highest one, reaching 89.6. The second one is Estonia with 87.5. The third one is Slovenia with 85.3. The bottom ten countries are: Afghanistan, Bangladesh, Laos, Myanmar, Nepal, Cambodia, Pakistan, India, Vietnam, Maldives, of which Afghanistan's is the smallest one, far behind of Singapore. The Bangladeshi is the second one with 42.3 and for Laos third with 48.5. And the average is only 36.8.

\subsubsection{Control variables}

The control variables of this paper mainly include the economic scale of the host country, the distance cost which is multiplied by the geographical distance between the two countries and the international oil price, the technical reserve of the host country, the natural resource endowment, infrastructure construction, the level of government regulation and the closeness of bilateral trade. The host country's purchasing power parity (PPP) which comes from the World Bank Development Indicators Database is adopted to reduce its endogeneity. The transportation cost is represented by the result of multiplication of the geographical distance and international oil price. The data about the distance is from CEPII, representing the distance between the capitals of the two countries. The international oil price data uses the spot price of the main crude oil in the WTI international market. The enrollment rate of the host universities is regarded as its strategic assets, the percentage of the country's ore and metal exports in the merchandise exports as the natural resource, the telephone holding per 100 people as the infrastructure level of the host country. These data are compiled based on the World Bank Development Indicators database. The government management efficiency of the World Bank's Global Governance Index (WGI) is represented by the host government's regulatory quality.

\subsection{Empirical analysis}

We use the stata14.0 software to get various descriptive indicators of variables, as shown in Table 2. It can be seen from the descriptive statistics of the data that the distribution of each variable is relatively scattered, which is beneficial to the empirical analysis below.

Specifically, from the descriptive statistics in Table 2, it can be found that the average value of the logarithm of China's OFDI along the 'Belt and Road' countries is 8.69. The maximum value is 15.02 for the direct investment stock of Singapore in 2016, so the investment gap in different countries is large. The average environmental regulations index in the host country is 69.46, the highest value is 91.05 in Singapore in 2008 and the lowest value is 34.17 in Afghanistan in 2007. Therefore, the difference among the host country's environmental regulations is also obvious. The logarithmic mean of the distance between the two countries and the price of oil is 12.93. The maximum is 13.667 for 2012 in Slovenia and the minimum is 10.83 for 2016 in Mongolia. The host country's national income has a logarithmic mean of 25.65 , with a maximum of 29.78 in India in 2016 and a minimum of 21.89 in the Maldives 
in 2007. The fastest growing economy in the host country is Azerbaijan in 2006, reaching $34.5 \%$. In 2009, Lithuania's economic growth rate was -14.81 . It can be seen that the level of economic development of the host country is quite different. Different countries vary a lot in the natural resource advantages of the host country, the construction of infrastructure, and national strategic countries. In terms of trade between China and the host country, the mean trade value of bilateral trade is 12.62, and the maximum is 16.18 in 2013 with Malaysia. In addition, China's direct investment in Malaysia is also relatively large.

Table 2. Descriptive data analysis

\begin{tabular}{|l|l|c|c|c|c|c|}
\hline \multicolumn{1}{|c|}{ Variables } & \multicolumn{1}{|c|}{ Name } & Observations & Mean & Std. Dev. & Min & Max \\
\hline China's foreign direct investment stock & Inofdi & 671 & 8.69 & 2.99 & 0 & 15.0229 \\
\hline Host country environmental regulations & epi & 671 & 69.46 & 11.9 & 34.17 & 91.05 \\
\hline $\begin{array}{l}\text { The distance between the two countries } \\
\text { and the price of oil }\end{array}$ & Indist_oil & 671 & 12.93 & 0.490 & 10.83 & 13.667 \\
\hline China's Gross National Income & Incgdp & 671 & 30.23 & 0.31 & 29.67 & 30.69 \\
\hline Host country Gross National Income & Ingdp & 671 & 25.65 & 1.55 & 21.89 & 29.78 \\
\hline Host country economic growth & gdpgrow & 671 & 4.343 & 4.79 & -14.81 & 34.5 \\
\hline Higher education enrollment rate & colle & 671 & 35.05 & 27.06 & 0 & 95.434 \\
\hline Natural resources (metal ore fuel) & res & 671 & 0.26 & 0.31 & 0 & 0.9998 \\
\hline Phone holdings per 100 people & Inphone & 671 & 4.67 & 0.65 & 0.37 & 5.48 \\
\hline Government governance efficiency & fe & 671 & -0.01 & 0.78 & -1.72 & 2.4369 \\
\hline Bilateral trade volume & Incomp & 671 & 12.62 & 2.03 & 0 & 16.1772 \\
\hline
\end{tabular}

Source: own elaboration using stata14.0 software.

\subsubsection{Full sample regression}

Considering the possible heteroscedasticity problem, this paper decides to adopt the natural logarithm method. In order to test whether there are multiple collinearity problems among these variables, the paper is to report the correlation coefficient matrix of the main variables, which is shown in Table 3. It can be seen from Table 3 that the correlation coefficients of the main variables are all below 0.7 , indicating that there is no multicollinearity between the variables. Further, it is found that the expansion variance factors are all less than 10; therefore, there is no systematic multicollinearity between the variables.

Regarding the choice of the test methods in this paper, the hybrid estimation, fixed effect model and random effect model are commonly used in panel data test models. In order to select the appropriate model, the paper first carries out the F test, and the result rejects the null hypothesis of the mixed regression model. Then the Hausman test is carried out. The results of this paper refuse to adopt the null hypothesis of random effects. Therefore, this paper uses the fixed effect model to empirically test the problem to be studied. 
Table 3. Correlation coefficient matrix

\begin{tabular}{|l|r|r|r|r|r|r|r|r|r|l|}
\cline { 2 - 11 } \multicolumn{1}{c|}{} & Inofdi & epi & Indist_oil & Inphone & gdpgrow & Incgdp & fe & res & colle & Incomp \\
\hline Inofdi & 1.0000 & & & & & & & & & \\
\hline epi & -0.2134 & 1.0000 & & & & & & & & \\
\hline Indist_oil & -0.3611 & 0.3856 & 1.0000 & & & & & & & \\
\hline Inphone & -0.0284 & 0.5852 & 0.3314 & 1.0000 & & & & & & \\
\hline gdpgrow & 0.0572 & -0.2819 & -0.1713 & -0.3367 & 1.0000 & & & & & \\
\hline Incgdp & 0.3920 & 0.0744 & -0.0644 & 0.3723 & -0.2458 & 1.0000 & & & & \\
\hline fe & -0.0874 & 0.5918 & 0.2492 & 0.5530 & -0.2548 & 0.0601 & 1.0000 & & & \\
\hline res & 0.1200 & 0.0064 & 0.0227 & 0.1413 & 0.0370 & -0.0222 & 0.0059 & 1.0000 & & \\
\hline colle & -0.1105 & 0.5743 & 0.2984 & 0.3899 & -0.3209 & 0.0466 & 0.2922 & -0.0680 & 1.0000 & \\
\hline Incomp & 0.7277 & 0.0177 & -0.1640 & 0.1198 & -0.0004 & 0.2288 & 0.1846 & 0.1528 & 0.0273 & 1.0000 \\
\hline
\end{tabular}

Source: own elaboration using stata14.0 software.

First, by the regression of the interaction of the host country's environmental regulations intensity, host country GDP and environmental regulations intensity, China's GDP level, and the distance between China and each host country and oil price, the results are shown in Table 4. It can be seen that the intensity of national environmental regulations along the 'Belt and Road' region is significantly negatively correlated with China's direct investment in the country, which indicates that the environmental protection measures implemented by 61 countries along the 'Belt and Road' have significantly inhibited direct investment in China. The interaction between the host country's GDP and the intensity of environmental regulations is significantly positive, indicating that the increase in the total economic output of the countries along the 'Belt and Road' will promote China's direct investment to a certain extent. It can also be seen that China's GDP level has significantly promoted the OFDI of the countries in the Chinese region. The coefficient of the distance between two countries is not significant, which may be related to the close distance between China and the countries along the 'Belt and Road. Therefore, the distance may not be the main consideration for China when investing in the countries along the 'Belt and Road' region. Considering the influence of other control variables on OFDI, the paper adds into the econometric model the host country's economic scale, host country technology reserve, host country natural resource endowment, host country infrastructure construction, government regulation level and bilateral trade closeness. The regression results are shown from (2)-(7) of Table 4. Column (2) of Table 4 shows that the size of the host country's economy has a positive effect on China's OFDI, in line with the expectations of this paper. Column (3) shows that the host country's strategic assets have significantly promoted China's OFDI, which is consistent with the expectations of this paper. Column (4) of Table 4 shows that natural resources in host countries have positive significant effects on China's OFDI, so it can be argued that China invests in natural resources for its purposes. Column (5) of Table 4 adds the host country's infrastructure construction variables, and the result is significantly positive, indicating that the local well-developed infrastructure has significantly promoted China's OFDI, in line with the expectations. Column (6) shows 
the government's regulatory level in the host country. The results show that the government's regulatory quality significantly inhibits China's direct investment in the EU, which is consistent with the empirical results of Liu Zaiqi and Wang Yang [2016]. Although the coefficient of the government regulations is negative, China cannot be considered to be biased towards investing in the 'Belt and Road' countries with poor government systems. The reason may be that there is a certain gap between China's institutional regulations and those of the countries along the 'Belt and Road'. These gaps may bring additional costs and risks to enterprises entering the countries along the route, while some host countries' imperfect systems will save costs, so promoting investment in these countries. That is why the overseas investment appears in such a host country.

Table 4. Full sample regression results

\begin{tabular}{|c|c|c|c|c|c|c|c|}
\hline & (1) & (2) & (3) & (4) & (5) & (6) & (7) \\
\hline VARIABLES & Inofdi & Inofdi & Inofdi & Inofdi & Inofdi & Inofdi & Inofdi \\
\hline \multirow[t]{2}{*}{ epi } & $-0.729 * \star \star$ & $-0.726^{\star \star *}$ & $-0.695^{\star \star *}$ & $-0.693^{* * *}$ & $-0.623^{\star * *}$ & $-0.692^{\star * \star}$ & $-0.653^{* * *}$ \\
\hline & (0.181) & $(0.181)$ & (0.180) & (0.181) & $(0.183)$ & $(0.184)$ & $(0.183)$ \\
\hline \multirow[t]{2}{*}{ Indist_oil } & 0.203 & 0.200 & 0.132 & 0.122 & 0.0816 & 0.0449 & -0.0944 \\
\hline & $(0.143)$ & (0.143) & (0.145) & $(0.146)$ & $(0.147)$ & $(0.147)$ & (0.151) \\
\hline \multirow[t]{2}{*}{ Incgdp } & $2.938^{\star * \star}$ & $2.961^{* \star \star}$ & $2.961^{* \star *}$ & $2.977^{\star \star \star}$ & $2.769 * \star \star$ & $2.755^{\star \star \star}$ & $2.446^{\star \star \star}$ \\
\hline & $(0.340)$ & $(0.348)$ & $(0.346)$ & $(0.347)$ & $(0.360)$ & $(0.358)$ & $(0.365)$ \\
\hline \multirow[t]{2}{*}{ epi_Ingdp } & $0.0261^{* * *}$ & $0.0259 * \star *$ & $0.0248^{* * *}$ & $0.0247^{\star * *}$ & $0.0224^{* * *}$ & $0.0252^{* \star *}$ & $0.0239 * * *$ \\
\hline & $(0.0072)$ & $(0.0072)$ & $(0.0072)$ & $(0.0072)$ & $(0.0073)$ & $(0.0074)$ & $(0.0073)$ \\
\hline \multirow[t]{2}{*}{ gdpgrow } & & 0.00361 & 0.00516 & 0.00534 & 0.00576 & 0.00455 & 0.00365 \\
\hline & & $(0.0116)$ & $(0.0115)$ & $(0.0115)$ & $(0.0115)$ & $(0.0115)$ & $(0.0114)$ \\
\hline \multirow[t]{2}{*}{ colle } & & & $0.0087^{* \star *}$ & $0.0088^{* * *}$ & $0.0088^{* * *}$ & $0.0092^{* * *}$ & $0.0097^{\star * *}$ \\
\hline & & & $(0.0032)$ & $(0.0032)$ & $(0.0032)$ & $(0.0032)$ & $(0.0032)$ \\
\hline \multirow[t]{2}{*}{ res } & & & & 0.241 & 0.154 & 0.172 & 0.189 \\
\hline & & & & $(0.404)$ & $(0.405)$ & $(0.403)$ & $(0.399)$ \\
\hline \multirow[t]{2}{*}{ Inphone } & & & & & $0.332^{* *}$ & $0.355^{\star *}$ & $0.259 *$ \\
\hline & & & & & $(0.155)$ & $(0.154)$ & $(0.155)$ \\
\hline \multirow[t]{2}{*}{ fe } & & & & & & $-0.827^{* *}$ & $-0.954^{* * *}$ \\
\hline & & & & & & $(0.336)$ & $(0.334)$ \\
\hline \multirow[t]{2}{*}{ Incomp } & & & & & & & $0.281^{* * *}$ \\
\hline & & & & & & & $(0.0792)$ \\
\hline \multirow[t]{2}{*}{ Constant } & $-78.61^{* * *}$ & $-79.21^{* * *}$ & $-78.79 * * *$ & -79.10 *** & $-74.61^{* * *}$ & $-74.02^{* * *}$ & $-66.43^{* * *}$ \\
\hline & $(9.483)$ & $(9.679)$ & $(9.630)$ & $(9.648)$ & $(9.845)$ & $(9.806)$ & $(9.947)$ \\
\hline Time fixed effect & yes & yes & yes & yes & yes & yes & yes \\
\hline Observations & 671 & 671 & 671 & 671 & 671 & 671 & 671 \\
\hline R-squared & 0.543 & 0.543 & 0.549 & 0.549 & 0.552 & 0.557 & 0.566 \\
\hline Number of country code & 61 & 61 & 61 & 61 & 61 & 61 & 61 \\
\hline
\end{tabular}

Source: own elaboration using stata14.0 software.

Note: ${ }^{*}{ }^{* *},{ }^{* *}$ are significant at the $10 \%, 5 \%$, and $1 \%$ levels, respectively, and the standard deviation of the coefficient estimates in the parentheses below the estimated coefficient. 


\subsubsection{Sample regression}

From the above descriptive data analysis, we can see that the economic development of countries along the 'Belt and Road' varies greatly, as does the level of environmental regulations in different locations. Therefore, this paper carries out sample regression from the perspective of the above three aspects.

\subsubsection{Economic development situation}

First, according to the National Income Classification Standard [2015 [published by the World Bank, countries along the 'Belt and Road' are divided into three categories. Then, the regression test is performed on the sub-samples. It can be seen from Table 5 of the regression results that the environmental regulations of low- and middle-income countries suppress China's OFDI, but the regression results are not significant. The environmental regulations of higher income and middle- and high-income countries are significantly negatively correlated with China's OFDI, and the environmental regulations level of high-income countries has a large impact coefficient on China's OFDI. This indicates that the level of environmental regulations in developed countries with high income levels is more sensitive to China's OFDI, resulting in a more significant offset. The close bilateral trade between low- and middle-income countries and China's high-income countries has significantly promoted China's OFDI, while the bilateral trade tightness between high-income countries and China has a positive impact on OFDI, but it is not significant. The regression results of the other variables in Table 5 are basically consistent with the results of the total sample regression and will not be described again.

Table 5. Sample regression results

\begin{tabular}{|l|c|c|c|}
\cline { 2 - 4 } \multicolumn{1}{c|}{} & $\begin{array}{c}\text { Low-and middle-income } \\
\text { countries }\end{array}$ & high-income countries & high-income countries \\
\hline VARIABLES & Inofdi & Inofdi & $-1.129^{\star * *}$ \\
\hline epi & $-0.157^{*}$ & $-0.323^{\star * *}$ & $(0.379)$ \\
\hline Indist_oil & $(0.0897)$ & $(0.0769)$ & -0.124 \\
\hline Incgdp & 0.0032 & -0.210 & $(0.383)$ \\
\hline & $(0.205)$ & $(0.252)$ & $2.526^{* * *}$ \\
\hline epi_Ingdp & $2.917^{\star * *}$ & $2.876^{\star * *}$ & $(0.688)$ \\
\hline & $(0.362)$ & $(0.354)$ & $0.0387^{\star *}$ \\
\hline gdpgrow & 0.0021 & $0.0134^{\star * *}$ & $(0.0153)$ \\
\hline & $(0.0036)$ & $(0.0027)$ & 0.0133 \\
\hline colle & -0.0126 & 0.0145 & $(0.0214)$ \\
\hline & $(0.0198)$ & $(0.0187)$ & 0.0073 \\
\hline res & 0.0100 & 0.0078 & $(0.0051)$ \\
\hline & $(0.0066)$ & $(0.0054)$ & 0.114 \\
\hline
\end{tabular}




\begin{tabular}{|c|c|c|c|}
\hline & $\begin{array}{l}\text { Low-and middle-income } \\
\text { countries }\end{array}$ & high-income countries & high-income countries \\
\hline VARIABLES & Inofdi & Inofdi & Inofdi \\
\hline \multirow[t]{2}{*}{ Inphone } & 0.160 & $0.0831 * *$ & 1.991 ** \\
\hline & $(0.183)$ & $(0.368)$ & $(0.783)$ \\
\hline \multirow[t]{2}{*}{ fe } & 0.127 & $-0.918^{* \star}$ & $-2.148^{* * *}$ \\
\hline & $(0.429)$ & $(0.376)$ & $(0.723)$ \\
\hline \multirow[t]{2}{*}{ Incomp } & $0.543^{\star * \star}$ & $0.414^{* * *}$ & 0.438 \\
\hline & $(0.180)$ & $(0.0826)$ & $(0.417)$ \\
\hline \multirow[t]{2}{*}{ Constant } & $-79.94^{\star \star \star}$ & $-83.20 * \star \star$ & $-59.12^{\star * *}$ \\
\hline & (10.61) & $(10.42)$ & (18.36) \\
\hline Time fixed effect & yes & yes & yes \\
\hline Observations & 242 & 220 & 209 \\
\hline R-squared & 0.435 & 0.545 & 0.495 \\
\hline Number of country code & 22 & 20 & 19 \\
\hline
\end{tabular}

Source: own elaboration using stata14.0 software.

Note: ${ }^{*}{ }^{* *},{ }^{* *}$ are significant at the $10 \%, 5 \%$, and $1 \%$ levels, respectively, and the standard deviation of the coefficient estimates in the parentheses below the estimated coefficient.

\subsubsection{Environmental regulation level}

The second option is to classify and test the countries along the line according to the intensity of environmental regulations. It is divided into two sub-samples whose environmental regulations intensity is less than the mean value and the environmental regulations intensity is greater than or equal to the mean value for regression analysis. The specific classification is shown in Table 6.

Table 6. Classification of national environmental regulations intensity along the 'Belt and Road'

\begin{tabular}{|c|c|}
\hline The intensity of environmental regulations & Country \\
\hline Less than the average of EPI & $\begin{array}{l}\text { Afghanistan, Bangladesh, Bahrain, Bosnia, Herzegovina, Nepal, Brunei Darussalam, } \\
\text { Georgia, Thailand, Indonesia, Qatar, the Arab Republic of Egypt, India, Uzbekistan, } \\
\text { the Islamic Republic of Iran, Cambodia, Kuwait, Iraq, Laos, Mongolia, Lebanon, Sri } \\
\text { Lanka, Maldives, Myanmar, Mongolia, Oman, Pakistan, Turkey, Vietnam }\end{array}$ \\
\hline Higher than or equal to the EPI & $\begin{array}{l}\text { Albania, the United Arab Emirates, Armenia, Azerbaijan, Bulgaria, Cyprus, Croatia, } \\
\text { Belarus, Hungary, Israel, Jordan, Kyrgyzstan, Lithuania, Kazakhstan, Latvia, Moldova, } \\
\text { Macedonia, Montenegro, Malaysia, Philippines, Poland, Romania, the Russian } \\
\text { Federation, Singapore, Serbia, the Slovak Republic, Saudi Arabia, Slovenia, Tajikistan, } \\
\text { Turkmenistan, Ukraine }\end{array}$ \\
\hline
\end{tabular}

Source: own elaboration on the basis of the National Environmental Sustainability Index developed by Yale University and Columbia University.

As shown in Table 6, the national environmental regulations level below the EPI mean significantly inhibits China's OFDI, while the host country's environmental regulations level above the EPI mean has a negative impact on China's OFDI, but it is not significant. According to the Investment Induced Factor Combination Theory, it can be known that foreign investment 
will be affected by some inducing factors. The difference between China's and the host country's environmental regulations can be one of the indirect inducing factors of China's OFDI. China's environmental regulations level is slightly lower than the national average level along the 'Belt and Road', and the lower than the regulatory level of the host country. The greater the gap with China's environmental regulations level is, the more it will stimulate China to directly invest in it. Thus, the national environmental regulations levels lower than the EPI mean have significantly inhibited China's foreign direct investment. The regression results of other variables are basically consistent with the results of the total sample regression and will not be described here.

Table 7. Sample regression results

\begin{tabular}{|c|c|c|}
\hline & Lower than the average of EPI & Higher than the average of EPI \\
\hline VARIABLES & Inofdi & Inofdi \\
\hline \multirow[t]{2}{*}{ epi } & $-0.331^{\star \star \star}$ & -0.389 \\
\hline & $(0.121)$ & $(0.270)$ \\
\hline \multirow[t]{2}{*}{ Indist_oil } & -0.160 & -0.136 \\
\hline & $(0.204)$ & $(0.222)$ \\
\hline \multirow[t]{2}{*}{ Incgdp } & $3.165^{\star \star \star}$ & $2.715^{\star \star \star}$ \\
\hline & $(0.382)$ & $(0.491)$ \\
\hline \multirow[t]{2}{*}{ epi_Ingdp } & $0.0113^{\star \star \star}$ & 0.0121 \\
\hline & $(0.0043)$ & $(0.0110)$ \\
\hline \multirow[t]{2}{*}{ gdpgrow } & 0.0124 & 0.00573 \\
\hline & $(0.0175)$ & $(0.0153)$ \\
\hline \multirow[t]{2}{*}{ colle } & 0.0094 & $0.0099 * * *$ \\
\hline & $(0.0069)$ & $(0.0038)$ \\
\hline \multirow[t]{2}{*}{ res } & 0.527 & 0.493 \\
\hline & $(0.395)$ & $(0.989)$ \\
\hline \multirow[t]{2}{*}{ Inphone } & 0.142 & $0.639 *$ \\
\hline & $(0.179)$ & $(0.387)$ \\
\hline \multirow[t]{2}{*}{ fe } & $-1.211^{\star \star \star}$ & -0.528 \\
\hline & $(0.380)$ & $(0.500)$ \\
\hline \multirow[t]{2}{*}{ Incomp } & 0.240 & $0.299 * * *$ \\
\hline & $(0.182)$ & $(0.0912)$ \\
\hline \multirow[t]{2}{*}{ Constant } & $-86.55^{\star \star \star}$ & $-73.14^{* \star *}$ \\
\hline & $(10.97)$ & (13.32) \\
\hline Time fixed effect & yes & yes \\
\hline Observations & 297 & 374 \\
\hline R-squared & 0.643 & 0.516 \\
\hline Number of country code & 27 & 34 \\
\hline
\end{tabular}

Source: own elaboration using stata14.0 software.

Note: ${ }^{*}{ }^{* *},{ }^{* *}$ are significant at the $10 \%, 5 \%$, and $1 \%$ levels, respectively, and the standard deviation of the coefficient estimates in the parentheses below the estimated coefficient. 


\subsubsection{The host country's position}

Finally, according to the different locations of the host country, the samples are divided into four regions. The sample regression results from the four regions are shown in table 8 .

Table 8. Sample regression results

\begin{tabular}{|c|c|c|c|c|}
\hline & European countries & $\begin{array}{l}\text { Middle East and North } \\
\text { Africa }\end{array}$ & East Asian countries & West Asian countries \\
\hline VARIABLES & Inofdi & Inofdi & Inofdi & Inofdi \\
\hline \multirow[t]{2}{*}{ epi } & $-0.363^{\star \star \star}$ & 0.311 & -0.949 & $-0.983^{\star \star}$ \\
\hline & $(0.0777)$ & $(0.386)$ & $(0.734)$ & $(0.453)$ \\
\hline \multirow[t]{2}{*}{ Indist_oil } & -0.236 & -0.341 & 1.083 & 0.0223 \\
\hline & $(0.207)$ & $(0.300)$ & $(0.468)$ & $(0.357)$ \\
\hline \multirow[t]{2}{*}{ Incgdp } & $1.940 * * *$ & $2.658 * * *$ & $5.174 * \star \star$ & 1.895 \\
\hline & $(0.270)$ & $(0.828)$ & $(1.637)$ & $(1.196)$ \\
\hline \multirow[t]{2}{*}{ epi_Ingdp } & $0.0136^{* * *}$ & -0.0113 & 0.0287 & $0.0394^{* *}$ \\
\hline & $(0.0026)$ & $(0.0147)$ & $(0.0278)$ & $(0.0178)$ \\
\hline \multirow[t]{2}{*}{ gdpgrow } & -0.0160 & 0.0090 & -0.0637 & -0.0039 \\
\hline & $(0.0138)$ & $(0.0179)$ & $(0.0510)$ & $(0.0295)$ \\
\hline \multirow[t]{2}{*}{ colle } & $0.0103^{* * *}$ & 0.0120 & $-0.0261^{*}$ & 0.0084 \\
\hline & $(0.0038)$ & $(0.0077)$ & $(0.0139)$ & $(0.0095)$ \\
\hline \multirow[t]{2}{*}{ res } & -0.838 & 0.111 & 0.178 & 1.497 \\
\hline & $(1.252)$ & $(0.552)$ & $(0.794)$ & $(1.079)$ \\
\hline \multirow[t]{2}{*}{ Inphone } & -0.0382 & 0.592 & -0.0846 & 0.402 \\
\hline & $(0.587)$ & $(0.558)$ & $(0.315)$ & $(0.445)$ \\
\hline \multirow[t]{2}{*}{ fe } & -0.0656 & -0.0774 & -1.199 & -1.191 \\
\hline & $(0.341)$ & $(0.521)$ & $(1.290)$ & $(0.810)$ \\
\hline \multirow[t]{2}{*}{ Incomp } & $0.370^{\star \star *}$ & 0.402 & 0.647 & 0.293 \\
\hline & $(0.0620)$ & $(0.312)$ & $(0.518)$ & $(0.327)$ \\
\hline \multirow[t]{2}{*}{ Constant } & $-51.60^{\star * *}$ & $-77.32^{\star \star \star}$ & $-135.6^{\star * \star}$ & $-57.16^{\star}$ \\
\hline & $(7.083)$ & $(23.65)$ & $(46.40)$ & (33.62) \\
\hline Time fixed effect & yes & yes & yes & yes \\
\hline Observations & 209 & 154 & 121 & 165 \\
\hline R-squared & 0.643 & 0.628 & 0.623 & 0.629 \\
\hline Number of country code & 19 & 14 & 11 & 15 \\
\hline
\end{tabular}

Source: own elaboration using stata14.0 software.

Note: ${ }^{*}{ }^{* *},{ }^{* *}$ are significant at the $10 \%, 5 \%$, and $1 \%$ levels, respectively, and the standard deviation of the coefficient estimates in the parentheses below the estimated coefficient.

According to the regression results in Table 8, it can be found that the environmental regulations of European countries and West Asian countries have significantly inhibited China's OFDI, while the influence of East Asian countries and Middle East and North Africa is not obvious. It may be that China's investment in Europe and West Asia is mostly in the 
energy industry, which has a greater impact on the host country's environment. Therefore, it is greatly affected by the host country's environmental regulations. In addition, it is worth noting that the strategic assets of European countries (the enrollment rate of higher education institutions) have a significant positive impact on China's OFDI, while the influence of other countries is not significant, so it is preliminarily possible to judge that China's investment objectives for European countries include its human resources. Moreover, the bilateral trade closeness between European countries and China is significantly positive with China's OFDI, indicating that the trade with European countries is conducive to promoting China's direct investment, while other regions are not obvious.

\section{Robustness test}

In order to test the robustness of the results, the first-order lag variable of the national environmental regulation along the 'Belt and Road' was used to replace the original variable as the model independent variable for the empirical test. The regression results are shown in Table 9. It can be seen that the coefficient of the main variable is not significantly changed, indicating that the conclusions of this study have good robustness.

Table 9. Results of the robustness test

\begin{tabular}{|c|c|c|c|c|c|c|c|}
\hline & (1) & (2) & (3) & (4) & (5) & (6) & (7) \\
\hline VARIABLES & Inofdi & Inofdi & Inofdi & Inofdi & Inofdi & Inofdi & Inofdi \\
\hline \multirow[t]{2}{*}{ epi } & $-0.729 * * *$ & $-0.726^{\star \star \star}$ & $-0.738^{\star * *}$ & $-0.735^{\star \star \star}$ & $-0.665^{\star \star \star}$ & $-0.732^{\star \star *}$ & $-0.696^{\star \star \star}$ \\
\hline & $(0.181)$ & $(0.181)$ & $(0.181)$ & $(0.181)$ & $(0.183)$ & $(0.185)$ & $(0.184)$ \\
\hline \multirow[t]{2}{*}{ Indist_oil } & 0.232 & $0.242^{*}$ & 0.176 & 0.171 & 0.140 & 0.112 & -0.0563 \\
\hline & (1.78) & (1.84) & (1.33) & (1.28) & (1.04) & $(0.84)$ & $(0.38)$ \\
\hline \multirow[t]{2}{*}{ Incgdp } & $3.934^{* * *}$ & $3.908^{\star \star \star}$ & $3.864^{* * *}$ & $3.868^{\star \star \star}$ & $3.610^{* * *}$ & $3.717^{\star \star \star}$ & $3.572^{\star \star \star}$ \\
\hline & (17.35) & (16.94) & (16.76) & (16.73) & (13.75) & (14.11) & (11.44) \\
\hline \multirow[t]{2}{*}{ epi_Ingdp } & $0.0261 * * *$ & $0.0259 * * *$ & $0.0263^{* * *}$ & $0.0261^{* * *}$ & $0.0239 * * *$ & $0.0266^{* \star *}$ & $0.0254^{\star * *}$ \\
\hline & $(0.0072)$ & (0.0073) & (0.0072) & (0.0073) & (0.0073) & (0.0074) & (0.0073) \\
\hline \multirow[t]{2}{*}{ gdpgrow } & & 0.00361 & 0.00314 & 0.00332 & 0.00373 & 0.00249 & 0.00147 \\
\hline & & $(0.0116)$ & $(0.0116)$ & $(0.0116)$ & $(0.0115)$ & $(0.0115)$ & $(0.0114)$ \\
\hline \multirow[t]{2}{*}{ colle } & & & $0.008^{* * *}$ & $0.008^{* * *}$ & $0.008^{* * *}$ & $0.008^{* * *}$ & $0.009 * * *$ \\
\hline & & & $(2.80)$ & $(2.79)$ & $(2.80)$ & (2.98) & (3.02) \\
\hline \multirow[t]{2}{*}{ res } & & & & 0.258 & 0.171 & 0.188 & 0.207 \\
\hline & & & & $(0.406)$ & $(0.406)$ & $(0.405)$ & $(0.401)$ \\
\hline \multirow[t]{2}{*}{ Inphone } & & & & & $0.320^{\star *}$ & $0.354^{\star *}$ & $0.295^{*}$ \\
\hline & & & & & (2.05) & (2.28) & (1.74) \\
\hline \multirow[t]{2}{*}{ fe } & & & & & & $-0.901 * \star *$ & -0.940 *** \\
\hline & & & & & & $(-2.85)$ & $(-2.94)$ \\
\hline
\end{tabular}




\begin{tabular}{|c|c|c|c|c|c|c|c|}
\hline & (1) & (2) & (3) & (4) & (5) & (6) & (7) \\
\hline VARIABLES & Inofdi & Inofdi & Inofdi & Inofdi & Inofdi & Inofdi & Inofdi \\
\hline \multirow[t]{2}{*}{ Incomp } & & & & & & & $0.279 * \star *$ \\
\hline & & & & & & & $(0.0796)$ \\
\hline \multirow[t]{2}{*}{ Constant } & $-78.61^{* \star *}$ & $-79.21 * * *$ & $-79.07^{\star \star \star}$ & $-79.40^{* \star \star}$ & $-74.86^{\star * *}$ & $-74.33^{* \star *}$ & $-66.78^{\star \star \star}$ \\
\hline & $(9.483)$ & $(9.679)$ & $(9.665)$ & $(9.684)$ & $(9.880)$ & $(9.848)$ & $(9.991)$ \\
\hline Time fixed effect & yes & yes & yes & yes & yes & yes & yes \\
\hline Observations & 610 & 610 & 610 & 610 & 610 & 610 & 610 \\
\hline R-squared & 0.543 & 0.543 & 0.545 & 0.546 & 0.549 & 0.553 & 0.562 \\
\hline $\begin{array}{l}\text { Number of country } \\
\text { code }\end{array}$ & 61 & 61 & 61 & 61 & 61 & 61 & 61 \\
\hline
\end{tabular}

Source: own elaboration using stata14.0 software.

Note: ${ }^{*},{ }^{* *},{ }^{* *}$ are significant at the $10 \%, 5 \%$, and $1 \%$ levels, respectively, and the standard deviation of the coefficient estimates in the parentheses below the estimated coefficient.

\section{Summary and recommendations}

\subsection{Research conclusion}

First of all, China's direct investment in countries along the 'Belt and Road' has shown a steady upward trend. Secondly, China's investment distribution in the 'Belt and Road' countries is uneven. Finally, the explanatory variable is consistent with the expectations. The research is shown below:

\subsubsection{In the full sample regression}

It was found that the strict environmental regulations of the host country significantly inhibited China's OFDI. Other factors have a great influence on the China 's OFDI, including the economic scale of the investment home country, the economic level of the host country, strategic resources, infrastructure, government regulation level, and bilateral trade tightness.

\subsubsection{As for the regression of income levels in the host country}

It is found that the environmental regulations of low- and middle-income countries suppress China's OFDI, but the regression results are not significant, while the environmental regulations of high-income and middle-income countries are significantly negatively correlated with China's OFDI.

\subsubsection{Relating to the regression of the environmental regulations level of the host country}

It is found that the national environmental regulations level lower than the EPI mean significantly inhibits China's foreign direct investment, while the host country's environmental 
regulations level higher than the EPI average level has a negative impact on China's foreign direct investment, but not significant.

\subsubsection{Considering the regression of different locations in the host country}

It was found that the environmental regulations of European countries and West Asian countries significantly inhibited China's OFDI, while the influence of East Asian countries and Middle East and North Africa was not obvious.

\subsection{Policy recommendations}

In order to better promote China's healthy and sustainable development of OFDI along the 'Belt and Road' countries, this paper proposes the following policy recommendations:

\subsubsection{Strengthening the assessment of the national environmental regulations level along the 'Belt and Road'}

The government should actively collect data on environmental regulations measures in the host country, especially high-income countries and European-Western countries. In order to select the best investment model, the environmental regulations of the countries along the 'Belt and Road' should be analyzed and the environmental regulations levels of the host countries classified.

\subsubsection{Creating a good international environment and establishing friendly relations}

From the government's perspective, we should persist in promoting bilateral friendly relations, reduce or even eliminate trade barriers, and actively create favorable conditions to promote Chinese enterprises' foreign trade, providing support and guarantee for Chinese enterprises to go out safely.

\subsubsection{Putting an emphasis on technological innovation and improving technical advancement}

Chinese enterprises that want to have core competitiveness in internationalization must pay attention to their science, technology and innovation capabilities, enhance research and development capabilities, and vigorously introduce high-tech talents. At the same time, with the improvement of technical advancement levels direct investment in host countries is conducive to reducing the extrusion of China's OFDI from host countries with similar technology levels.

\subsubsection{Improving risk awareness and avoiding investment risks}

When investing in foreign countries, enterprises should pay attention to increased risk awareness and knowing the status of the host country in advance, including the government 
regulation level, legal risks, and social and cultural risks, and take some measures to circumvent the institutional legal risks of the host country and avoid trade barriers.

\section{References}

1. Buckley, P.J., Clegg, L.J., Cross, A.R., Liu, X., Voss, H., and Zheng, P. (2007). The determinants of Chinese outward foreign direct investment. Journal of International Business Studies, No. 38(4), pp. 499-518.

2. Chen Xuan, Wu Ge (2010). Analysis of the Impact of Environmental Regulation on FDI - An Empirical Analysis Based on Guangdong. Special Economic Zone, No. 4, pp. 32-34.

3. Chung, S.H. (2014). Environment Regulation and Foreign Direct Investment: Evidence from South Korea. Journal of Development Economics, Vol. 108, No. 5, pp. 222-236.

4. Debashis Chakrabortya, Sacchidananda Mukherjeeb (2013). How do trade and investment flows affect environmental sustainability? Evidence from Panel Data. Environmental Development, Vol. 6, No. 4, pp. 34-47.

5. Deng, P. (2003). Foreign Direct Investment by Transnational from Emerging Countries: The Case of China. Journal of Leadership and Organizational Studies, No. 10(2), pp. 113-124.

6. Dunning, J.H. (1977). Trade, Location of Economic Activity and the MNE: A Search for an Eclectic Approach. [In:] The International Allocation of Economic Activity. B. Ohlin, P.O. Hesselborn, and P.M. Wijkman (Eds.). London: MacMillan, pp. 395-418.

7. Fu Jingyan, Li Lisha (2010). Empirical Research on Environmental Regulation, Factor Endowment and Industrial International Competitiveness. Management World, No. 10, pp. 87-98.

8. Gao Jing, Liu Guoguang (2011). The Research on FDI District Agglomeration of Multinational Producer Services. Economy and Management, Vol.25; No. 20910, pp. 76-80.

9. Grossman, G. and Krueger, A. (1991). Environmental Impacts of the North American Free Trade Agreement. NBER Working Paper No. 3914.

10. Guo Jianwan, Tao Feng (2009). Agglomeration Economy, Environmental Regulation and Location Choice of Foreign Direct Investment - Based on the Analysis of New Economic Geography. Industrial Economics Research No. 4, pp. 29-37.

11. Haeyeon Yoon, Almas Heshmati (2017). Do environmental regulations effect FDI decisions? The pollution haven hypothesis revisited. IZA Institute of Labour Economics, IZA DP No.10897. pp. 1-21.

12. Henderson, J.V. (1996). Effects of Air Quality Regulation. American Economic Review No. 86(4).

13. Hu Desheng, Ou Jun (2016). The Environmental Responsibility of Chinese Enterprises Directly Investing in Other Countries in the "Belt and Road". Journal of Xian Jiaotong University (Social Science Edition), No. 04, pp. 45-51.

14. Javorcik, B.S., Spatareanu, M. (2005). Do Foreign Investor Care about Labor Market Regulation? Review of World Economics, Vol. 141, No. 3, pp. 375-403.

15. Jiang Guanhong, Jiang Dianchun (2012). Location Selection of China's Foreign Investment: Panel Data Inspection Based on Investment Gravity Mode. World Economy No. 9, pp. 21-40.

16. Jiang Dianchun, Zhang Qing Chang (2011). Analysis of the Gravity Model of American Direct Investment in China. The Journal of World Economy, No. 5, pp. 26-41. 
17. Joanne E. Oxley (1999). Institutional Environment and the Mechanisms of Governance: The Impact of Intellectual Property Protection on the Structure of Inter-firm Alliances. Journal of Economic Behavior \& Organization, Vol. 38, No. 3, pp. 283-309.

18. Kellenberg D. (2009). An empirical investigation of the pollution haven effect with strategic environment and trade policy. Journal of International Economics, No. 78(2), pp. 242-255.

19. Keller, W. Levinson, A. (2002). Pollution Abatement Costs and Foreign Direct Investment Inflows to US States. Review of Economics and Statistics, Vol. 84, No. 11, pp. 691-703.

20. Levinson A. (1996). Environmental regulations and manufacturers' location choices: Evidence from the Census of Manufactures. Journal of Public Economics, Vol. 62, No. 2, pp. 5-29.

21. Li Gang, Li Ying (2012). Theory and Empirical Progress of Environmental Regulation Intensity Measurement. Economic Management, No. 12, pp. 154-165.

22. Li Guoping, Yang Peigang, Song Wenfei, Han Xianfeng (2013). Environmental Regulation, FDI and "Pollution Shelter" Effect: An Empirical Analysis of the Heterogeneity Perspective of China's Industrial Sector. Science of Science and Management of S. \& T, No. 10, pp. 122-129.

23. Liu Yang, Zhang Rui, Gao Yanhong (2014). Construction and Measurement of China’s Environmental Regulation Performance Evaluation Index System. Business Times, No. 4, pp. 115-117.

24. Liu Zaiqi, Wang Yang (2016). Economic Resources, Institutional Environment and Location Choice of China's Direct Investment in the European Union. Economic Management, No. 02, pp. 1-13.

25. Meng Qingqiang (2016). An Empirical Study of China's Direct Investment Motivation in Countries along the Belt and Road Initiative. Industrial Economic Forum, No. 3(02), pp. 136-144

26. Millimet, D.L., Ray, J. (2016). Empirical Tests of the Pollution Haven Hypothesis When Environmental Regulation Is Endogenous. J. Appl. Econ., Vol. 31, pp. 652-677.

27. Ni Sha, Wang Yongxing, Jing Weimin (2016). Analysis of China's Gravity of Direct Investment in Countries along the Belt and Road Initiative. Modern Financial Economics, No. 5, pp. 3-14.

28. Oh, J.Y. (2014). The Effect of Environmental Regulation Stringency on the FDI of Korea's pollution intensive industry [D]. Seoul National University,

29. Qiu Qiang, Wang Sai, Zhang Tongxun (2018a). Research on the Impact of Environmental Regulations in Asia-Pacific Countries on China's OFDI. Asia-Pacific Economy, No. 1, pp. 120-125.

30. Qiu Qiang, Zhang Tongxun, Wang Sai (2018b). Study on the Impact of Environmental Regulations of 16 Countries in Central and Eastern Europe on China's OFDI, China-Central and Eastern European Countries Cooperation Progress and Achievements. China Social Sciences Press, No. 9, pp. 93-111.

31. Ren Li, Huang Chongjie (2015). The Impact of Environmental Regulations at Home and Abroad on China's Export Trade. World Economy, No. 5, pp. 59-80.

32. Song Malin, Wang Shuhong (2013). Environmental Regulation, Technological Progress and Economic Growth. Economic Research, No. 3, pp. 122-134.

33. Su Hongyan, Li Jingmei (2017). An Empirical Study on the Spatial Layout and Pollution Transfer of FDI Countries along the Belt and Road Initiative. Soft Science, No. 3, pp. 25-29.

34. Susan F. Stone and Bang Nam Jeon (2000). Foreign Direct Investment and Trade in the Asiapacific Region: Complementarity, Distance and Regional Economic Integration. Journal of Economic Integration, No. 3, Vol. 15, pp. 460-485 
35. Tian Suhua, Yang Wei (2012). Determinants of FDI Entering China’s Location Change: Empirical Research Based on D-G Model. World Economy, No. 11, pp. 59-87.

36. Tian Yuan, Li Jianjun (2018). China's Location Choice for OFDI along the "Belt and Road" Countries. Exploration of economics, No. 1, pp. 79-88.

37. UNCTAD (2006). United Nations Conference on Trade and Development, UNCTAD annual report 2006, pp. 2-19. Retrieved from: https://unctad.org/ch/docs/dom20071_ch.pdf

38. Wagner, U., Timmins, C. (2009). Agglomeration effects in foreign direct investment and the pollution haven hypothesis. Environmental and Resource Economics, No. 43(2), pp. 231-256.

39. Walsh, J.P. and Yu Jiangyan (2010). Determinants of Foreign Direct Investment: A Sectoral and Institutional Approach. IMF Working Papers, Vol. 7, pp. 1-27.

40. Wang Sheng, Tian Tao (2013). Research on the Factors Affecting the Location Choice of China's Foreign Direct Investment - Based on the Perspective of Country Differences. World Economic Research, No. 12, pp. 60-66.

41. Wang Ying, Lu Wei, Tang Ziyi (2018). Research on the Factors Affecting China's Direct Investment in the Countries Along the Belt and Road Initiative - Based on the Environmental Factors of Host Country System. International Trade Issues, No. 1, pp. 83-91.

42. Wang Yongqin, Du Juzhen, Wang Kai (2014). Determinants of China's Foreign Direct Investment Location Selection: System, Tax Burden and Resource Endowment. Economic Research, No. 12, pp. 126-142

43. Xing Y.C.D. Kolstad (2002). Do lax environmental regulations attract foreign investment. Environmental and Resource Economics, Vol. 21, No. 1, pp. 1-22.

44. Xiong, B, Wang, M. (2018). Study on the Influencing Factors of Chinese OFDI in Countries along the "Belt and Road": Based on Spatial Perspective. Journal of International Trade, No. 2, pp. 102-112.

45. Xu Qiqi (2015). Construction and Empirical Test of Mathematical Model of Green Technology Innovation under Environmental Regulation [D]. Jilin University.

46. Xu Xiaoping, Lu Jing, Li Jiang (2016). The Impact of Signing Bilateral Investment Agreements on China's OFDI - An Empirical Study Based on Countries along the Belt and Road Initiative. Industrial Technology\& Economy, No. 5, pp. 60-64.

47. Zhao Yumin, Zhu Fangming, He Lilong (2009). Within the Definition, Classification and Evolution of Environmental Regulation. China Population, Resources and Environment, No. 6, pp. 85-90.

48. Zhou Wei, Chen Shao et al. (2017). China's National Risk Study of the "Belt and Road" OFDI: Based on the Quantitative Evaluation of 39 Host Countries along the Route. World Economic Research, No. 4, pp. 1-9.

49. Zhu Wei, Ren Rongming (2015). Export, Environmental Pollution and Foreign Direct Investment - Based on the Empirical Test of China Provincial Panel VAR from 2003 to 2012. Ecology and Economy, No. 6, pp 36-40.

50. Zhushujin, Yinshixue (2014). Does Trade of Polluted Industries Lead to A "Race to the Bottom" in Environmental Regulation? Evidence from Cross-Country Panel Data. Industrial Economics Research, No. 4, pp. 41-51. 